\title{
Towards Social Justice in Education: Contradictions and Dilemmas
}

Prof Becky Francis (UCL Institute of Education), Prof Martin Mills (University of Queensland), and Prof Ruth Lupton (University of Manchester)

\section{Contact:}

Becky Francis

Institute of Education

20 Bedford Way

London

e-mail B.Francis@ucl.ac.uk 
Towards Social Justice in Education: Contradictions and Dilemmas

\begin{abstract}
The article builds on prior arguments that research on issues of social justice in education has often lacked constructive engagement with education policymaking, and that this can be partly attributed to a lack of clarity about what a socially just education system might look like. Extending this analysis, this article argues that this lack of clarity is perpetuated by a series of contradictions and dilemmas underpinning 'progressive' debate in education, which have not been adequately confronted. At the heart are dilemmas about what constitutes a socially just negotiation of the binarised hierarchy of knowledge that characterises education in the UK, Australia and elsewhere. Three exemplar cases presented from contemporary education curriculum policy in England and Australia are used to illustrate these dilemmas. We then extend this argument to a series of other philosophical dilemmas which haunt education and create tensions or contradictions for those concerned with social justice. It is maintained that we need to confront these dilemmas in efforts to extend conceptual clarity in what it is we are seeking to achieve; which in term can better equip us to provide the empirical and conceptual information necessary to effectively engage policymaking to remediate inequalities in education.
\end{abstract}




\section{Towards Social Justice in Education: Contradictions and Dilemmas}

\section{Introduction}

This article seeks to interrogate some dichotomies and tensions appearing in work on social justice in education. It develops challenges raised previously in a journal special issue, and papers written by two of the authors, wherein we asked what a socially just education system would look like. Those writings were generated by our concern about a tendency in the literature to critique present trends in the education system, without drawing on empirical or philosophical evidence to make constructive suggestions for preferential practice. We also argued that these critiques are sometimes contradictory. In this article we suggest that an impetus to support those perspectives, organisations, literature and movements traditionally associated with Left-Wing ('progressive') ideological positions has resulted in various contradictions within work in this field. We argue further than many of the debates around social justice and current injustice in the education system coalesce around several longstanding binaries that characterise debates about social justice in education (Francis \& Mills 2012a). This article is intended to unpick some of the philosophical and practical conundrums that challenge the field and, we would argue, require direct confrontation if we are going to be able to move beyond accounts of injustice to proposals for more just alternatives. In this sense, we argue that these dilemmas are urgent to address, in supporting both the intellectual rigor of the field, and the clarity of evidence to influence practice and policy.

In the writing of the article we were confronted by these dilemmas as we sought to write a coauthored paper. At times we debated the extent to which we individually appeared to be favouring one position over another, at the same time we also recognised each other's commitments to a schooling system that meets the needs of all students, but especially those who have been marginalised by social injustices, however perpetrated. In this sense we are mutually committed to an essentially humanist - albeit social constructionist - view of public education systems as a) potentially emancipatory, and b) under threat in many parts of the world. Nevertheless, as we elaborate below, we are also deeply aware of the role of public education systems in reproducing and legitimising inequity; and of the complexity of the myriad issues at stake in this terrain. We thus seek to provoke dialogue and debate on, rather 
than solve, the conundrums faced by those working in the diverse fields associated with social justice and education. In order to do so, we present three exemplar cases from contemporary education curriculum policy in England and Australia to illustrate these dilemmas. We then extend this argument to a series of other philosophical dilemmas which haunt education and create tensions or contradictions for those concerned with social justice. We primarily draw upon examples from the UK and Australia, the locations of the authors of this paper. While we recognise that these locations are not necessarily indicative of global issues and policy trends, we would suggest that the points made have purchase beyond these contexts, not least because of the increasing globalisation of education policy (Ball 2013) and the global extension of practices of policy borrowing already long established between Western nations (Whitty 2016; Lingard 2010; Mills \& McGregor 2016).

\section{Background}

Having positioned this paper as addressing dilemmas in the field of education and social justice, we first briefly set out the current context and the paper's parameters. A key issue is the notion of social justice itself. Education researchers exploring issues of social justice analyse education policy through different lenses, reflecting different conceptions of social justice (and consequent prioritisation of different elements, e.g. distribution, recognition or representation) (see e.g. Fraser 1997, 2009; Olson 2008; Young 2004; Sen 2011 for discussion). In our own national contexts, inequalities of educational experience and outcome remain strongly evidenced, in relation to gender, ethnicity, socio-economic background and a variety of other indicators. In relation to ethnicity and gender, while research documents continuities of inequality in many areas, there have also been some significant shifts, such as the increase in women now attending higher education (Hillman \& Robinson 2016); the improved performance of girls as a group at STEM subjects within compulsory education (Arnot et al. 1999; Francis \& Skelton 2005) ${ }^{\mathrm{i}}$; and the increased performance of certain minority ethnic groups in compulsory education (DfE 2016), all of which raise important questions about whether systems are now more socially just and in what ways. However, the focus of this article is on socio-economic differentials in experience and outcome. Socioeconomic background remains the strongest predictor of educational attainment in the UK context (Lupton et al. 2009; Strand 2011), and is likewise a strong indicator of education outcomes in the Australian case too (although it is important to note that in Australia, Indigenous students still face inequities of the highest order (Teese \& Polesel 2003; Ford 2013) and of course that there are multiple intersections of gender, ethnicity, socio-economic 
status, sexual orientation, migration status and other factors that necessarily affect educational experiences and outcomes in complex ways.

Arguments about how to achieve social justice in education have been played out over many decades. Sometimes forgotten in debates on current educational inequality is that social class inequalities have characterised British state education since its introduction, and remained firmly entrenched even through the period of comprehensivisation in the 1960s and ' $70 \mathrm{~s}$ (Francis and Mills 2012b; for discussion of the Australian context see Campbell \& Proctor 2014). Recent international neoliberal policy trends including marketisation of education, the increased blurring of the public and private as private sector practices and providers are welcomed in to state education provision (Ball 2013; Hogan 2014), and diversification of education offers in efforts to provide choice for 'consumers' of education (Mills et al. 2014), have been positioned as being particularly problematic and inequitable, but the long standing nature of inequalities cannot be ignored. Nor, indeed, can evidence of recent progress. In the UK, since the late 1990s, there has been evidence of a narrowing of socio-economic gaps for educational attainment (Heath et al. 2013), although: the gap remains especially wide for higher levels of attainment (Jerrim 2012; Blanden and Macmillan 2013); the socio-economic gap indicated by free school meals has narrowed slightly in primary schooling but not in secondary (Lupton \& Thompson 2015); and there are pronounced regional differences, with particular progress being made in London (Burgess 2014; Greaves et al. 2014; CfBT 2014). The persistence of large inequalities through a period of profound economic change, combined with the 'London phenomenon', suggest the need for historical and spatially situated analysis rather than broad statements either that 'it was ever thus' or that the contemporary situation is particularly problematic.

An interest in social inequality in educational outcomes has been a feature of successive Government policy-making in the UK and Australia in the Twenty-first Century. Given our arguments in this article, it is worth acknowledging that this recognition in both the UK and Australian contexts can be at least partially credited to the findings and influence of the OECD. The OECD has been influential in motivating international education policy developments via the growing influence of the international league tables enabled by PISA testing (Sellar \& Lingard 2014; Whitty 2016). These practices have been castigated for their promulgation of competitive approaches, and application and encouragement of New Public Management techniques to global education (Rizvi \& Lingard, 2009). However, the OECD 
has consistently foregrounded investigation of social inequalities in educational outcomes as part of their PISA research agenda (e.g. OECD 2010a; 2013) ${ }^{\mathrm{ii}}$, although it has led to a rearticulating of social justice as 'equity' in the Australian policy domain (Lingard, Sellar \& Savage 2014). This has demonstrably raised the profile of social inequalities in education, and maintained this issue as a key policy focus (Whitty 2016), providing statistical information frequently drawn upon by researchers, commentators and policy makers interested in social justice. In most countries of the Global North then, including the UK and Australia, there is political consensus that social inequalities in educational outcomes need to be addressed. The question is how.

The UK Labour government from 1997-2010 took an approach based on centrally driven school improvement (including closing 'failing' schools in disadvantaged areas and replacing them with Academies, and centrally-mandated curriculum initiatives such as the National Literacy and Numeracy strategies), additional funding for schools in areas of disadvantage, area-based initiatives, and the introduction of a wider range of vocational qualifications to increase engagement and qualification rates (Lupton \& Obolenskaya 2013). Its Conservative/Liberal Democrat Coalition successor continued to redistribute funding (via its 'Pupil Premium') (Lupton \& Thompson 2015), but also focused on realising social mobility and meritocractic ${ }^{\mathrm{iii}}$ outcomes via increased equality of opportunity in access. For example, taking up evidence that few working class young people access the academic curriculum and qualifications demanded by selective universities (e.g. Richmond \& Freedman 2009), and that the vocational training routes which many working class young people were being directed down were not fit for purpose (Wolf 2011), the Coalition Government designed a curriculum and indicators incentivising a knowledge-based curriculum for all; an agenda that is being extended by the current Conservative Government ${ }^{\mathrm{iv}}$. It also further strengthened school accountability, giving enhanced importance to 'closing the gap'. The position that the needs of the most marginalised students would be best served by greater accountabilities was also taken up by the Australian Labor government and its Coalition successor: for example, through the transparent publication of student results on national tests via the MySchool website (Thompson 2013). State governments, which have primary jurisdiction over government schools have implemented their own various approaches (see for example, Queensland's Teaching and Learning Audit, Mills et al. 2014) to ensure that regardless of background all students were presented with similar opportunities to succeed. 
In this policy context, those working in the fields of social justice and education have argued that an approach that focuses exclusively on distribution of opportunity will never be sufficiently radical or comprehensive to address either the inequalities of recognition demonstrated through the literature (Gewirtz 2001), or indeed to effectively address inequality of outcomes (Beach 2015; see also Keddie 2012a). Social mobility approaches have been criticised for being premised on an acceptance of inequality, albeit based on 'merit' rather than dynasty (Beach 2015, see also Arendt [1954] for an articulation of this point); and for a focus on individualised solutions likely to be undermined by multiple inequalities (Fraser 1997; 2009; Young 2004).

However, whereas the social mobility approach may be flawed in both its methodology and ends, the proposed methods and ends are at least transparent. It is arguable that, conversely, education academics concerned with social justice have often been less clear on what socially-just education provision would look like (Francis \& Mills, 2012a); and how such a vision might be achieved. This may partly be explained by the different philosophical positions and connected interests they adopt. However, it may arguably also reflect a lack of clarity, and a tendency to perpetuate longstanding binarised constructions due to an empathetic association with historic 'progressivism' in education. The risks of such positioning were arguably illuminated by the recent debates on the curriculum reforms in the UK, in which the then Secretary of State for Education Michael Gove characterised 'progressive' academics and educationalists resisting his education reforms as upholding the social status quo and vested interests - his disparaging branding of these 'forces' as 'The Blob’ proving a peculiarly effective discursive signifier in wider political commentary (Francis 2014). Academics who had criticised his drive towards a more knowledge-based, 'traditional' curriculum were positioned as complacent advocates of 'sheep and goats' social class segregation, and as maintaining double standards (Gove 2013b). Other social commentators have made similar arguments (Old 2013).

While not supporting Michael Gove's polarising rhetoric, we do think that his comments indicate the need for those of us in the field to make our positions clearer, resorting less to a general progressivism and working harder to resolve some of the difficult questions and tensions about what an education policy based on social justice would look like. In the following sections we identify these tensions as they relate to hierarchies of knowledge and to the organisation and delivery of education through contemporary schooling practices. 


\section{Hierarchies of knowledge}

At the heart of these tensions is an historic dichotomy underpinning understandings and debates about the nature, purpose and direction of education. This dichotomy especially underpins perennial debates on the content of education - the curriculum. It can be sketched thus:

$\begin{array}{lcl}\text { Vocational } & \text { v } & \text { Academic } \\ \text { Skills } & \text { v } & \text { Knowledge } \\ \text { Progressive } & \text { v } & \text { Traditional } \\ \text { Soft } & \text { v } & \text { Hard } \\ \text { Dumbed down } & \text { v } & \text { Rigour } \\ \text { Mass } & \text { v } & \text { Elite } \\ \text { Arts \& humanities } & \text { v } & \text { Sciences } \\ \text { Body } & \text { v } & \text { Mind } \\ \text { Enquiry } & \text { v } & \text { Facts } \\ \text { Extrinsic } & \text { v } & \text { Intrinsic }\end{array}$

This dichotomy speaks to the historic Western valuing of 'mind' over body, and intellectual activity over practical skills, which elevates some subjects over others and positions skillsbased learning as easier and less valuable than 'academic' learning. Discursive practices reflecting this dichotomy position the competence and enquiry-based education advocated by those characterised as 'progressive', such as John Dewey, as relational to a more 'rigorous', top-down education based on consumption of 'the best that has been said and thought' (Arnold, 1869; see e.g. Young, 2007; 2011; Hirsch, 1996; or Old, 2013, for illustration of these debates). Moreover, the column on the right signifies as powerful via othering and devaluation of the column on the left. Not surprisingly, it has been education for the elite that has shaped and reflected the column on the right. As Paechter (2000) has outlined, the curriculum as developed in the early public schools in the UK was designed to support the needs of the aristocracy (and later the emergent bourgeois class); and the curriculum in schools for the poor, when these finally emerged in the $19^{\text {th }}$ Century, looked very different. The latter was focused on skills potentially needed for manual/semi-skilled labour and for 'healthy' living (moral and physical) (Purvis, 1989; Maguire et al, 2006). Hence a 'sheep and 
goats' differentiation of the type of education and knowledge considered appropriate for different classes of young people has a long history in the UK - and in Australia, which closely followed the British model. It also continues into the present, albeit present Governments in both countries are seeking in various ways to address this. The ethical and conceptual challenges raised by class-segregated curriculum offers that reflect the above dichotomy, and policy attempts to alleviate these, can be illustrated by three contemporary examples, one from Australia and two from England.

\section{Example 1}

The collapse in the youth labour market in Australia in the 1970s led to higher levels of school retention in the senior years. The traditional academic curriculum, that had been the staple for those who harboured tertiary education ambitions, was deemed no longer sufficient for many students who were the first in their families to progress beyond the junior years. This led to a differentiation of individual academic subjects such as mathematics, where new forms of mathematics such as 'Trade Mathematics' and 'Ordinary Mathematics' became an option for students. However, these watered down subjects, in the case of mathematics colloquially referred to as 'veggie maths' by students and teachers alike in various Australian states, did not qualify students for university entrance. This differentiation was premised on the dichotomy of either preparing students for the workforce or a tertiary education institution. However, as Teese and Polesel (2003: 33) indicate, it was not only this dichotomy that underpinned curriculum reform in Australia but also an extended liberal concept of education which saw the introduction of senior school subjects such as Dance, Media Studies, Studies of Society and Aboriginal and Torres Strait Islander Studies. As an equity measure and as an attempt to address critiques of this form of differentiation, some of these subjects have become eligible for consideration for tertiary entrance scores. However, the curriculum hierarchies were not challenged in any significant ways as the 'hard' 'academic' subjects contribute far more to tertiary entrance scores in Australian states than do others.

Furthermore, the valued nature of traditional subjects has been evidenced by their treatment in Australia's national curriculum, which prioritised a focus on Mathematics, the Sciences and English (these became the first national curricula to be produced in 2012, followed by History in 2013 and Geography in 2015; see Mills \& McGregor 2016 for discussion). This may well be read as the Arts, vocational curricula and other non-academic curricula not being 
seen as worthy of national effort and resources and the further entrenching of the value of the curricula and pathways taken by the middle classes.

\section{Example 2}

In England, there has been a longstanding trend for state schools to direct their working class pupils towards vocational qualifications. Of course, some of this is about choice, and it is arguable that all young people should be offered a mix of subjects that would traditionally be termed 'vocational' and 'academic'. However, under the previous New Labour administrations in the UK, drivers of two different markets in education in England resulted in the 'mis-selling' of qualifications to young people, of whom the majority were working class (Wolf 2011). Schools, under pressure to raise student attainment indicators in order to recruit potential students, were supplied qualifications to enable this by exam boards keen to sell their products. The result was a massive growth in 'equivalent' vocational qualifications, wherein a (non GCSE) qualification in a vocational area was said to 'count' for the equivalence of several academic GCSE qualifications. The problem was that these 'equivalent qualifications' were shown to have little recognition or exchange value in the workplace (Wolf 2011). And it was young people from lower socio-economic backgrounds who were the overwhelming recipients of these qualification routes. Hence, this is a very significant issue for social justice.

Nevertheless, the issues are more complex than is often recognised by Government: for example, a portion of young people remain - for many different reasons - unable to access and successfully engage a mainstream curriculum (Francis 2015; McGregor \& Mills 2012). Commentators are right to raise concerns about marginalised groups of students missing out on powerful forms of knowledge (Young 2011; 2013; see also Mills et al. in press), and we agree that the size of this group of students can and should be reduced. However, it remains the case that those students unable to successfully engage a mainstream 'academic' curriculum, vocational and/or foundational qualifications offer alternative accreditation and recognition preferable to exiting school with nothing. Such qualifications may also promote important life skills and engagement (Harrison et al, 2015). There is also a troubling gap emerging between those students entered for the $\mathrm{EBacc}^{\mathrm{v}}$ in England and those achieving it and the gap for young people from disadvantaged backgrounds is particularly large (Hutchings et al 2016). Hence, one task in relation to the provision of a socially just 
curriculum might be to consider how to transmit powerful knowledges, whatever they might be (Young 2013), via a non-traditional curriculum (see for example, Apple \& Beane 1999).

\section{Example 3}

The counter side to such provision of a highly differentiated curriculum is the continuing elevation of 'traditional' academic subjects, which is the case in both England and Australia. In many locations the withdrawal of vocational options and the devaluing of the arts is widely reported to be narrowing curriculum choice, alienating students and resulting in lower school engagement (Bleazby 2015; Stinson \& Saunders 2016). An insistence that students study an expanded collection of 'traditional' academic subjects at the expense of arts, design, vocational and social science subjects, for example has meant that many students who were already disengaged from the former set of subjects no longer have options to learn material that is of interest to them. However, it is understandable why governments and schools might do this in the interests of social justice and to ensure that their students' future options, especially for those from marginalised backgrounds, are maximised. It remains true that 'academic' subject qualifications significantly and demonstrably provide the best returns in future remuneration (Iannelli 2013).

Supporting this impetus have been the Higher Education sector gatekeepers that operationalise subject hierarchies in their (selective) admissions. In the UK, for example, in the interests of 'widening participation' the prestigious Russell Group universities have tried to promote transparency on their preferences by publishing a document on the 'facilitating subjects' which will best aid access to these institutions (Russell Group 2012). The need for transparency was to some extent driven by recognition that the private school sector, highly attuned to these cultural preferences of the leading universities, were overwhelmingly providing a heavily academic curriculum to their pupils, facilitating higher rates of entrance. High achieving working class young people have been shown to be significantly less likely to pursue such subjects at 'A' Level compared to their middle-class counterparts (Sutton Trust, 2015). The values and rationales underpinning these subject preferences on the part of universities are rarely questioned or articulated (Candy 2012), but they reflect and embed the hierarchical dichotomy we outlined above.

These three examples have all illustrated genuine conundrums both epistemological and practical; the impact of the longstanding hierarchical dichotomy in different 'kinds' of 
knowledge reflected in school curricula; and the difficulty in finding 'just' approaches that accommodate these various challenges and dilemmas. The dichotomy in relation to skills/knowledge, vocational/academic education may be especially characteristic of particular education systems. However, researchers also report such discursive trends underpinning hierarchies of practice and outcome in many other nations (see e.g. Jonsson \& Beach 2015; Beach 2015). For example, Jonsson \& Beach (2015) argue that, even in the Nordic bloc (where public services tend to be perceived externally as highly progressive and equitable, see e.g. Wilkinson \& Pickett 2010), education follows similar social class trends in the direction of working class students into vocational study afforded less status than academic study. Albeit, this segregation takes place later than in many other European nations. Jonsson and Beach (2015) argue that despite the rhetoric of equity and social justice in the Scandinavian context, social background and other social variables such as gender, ethnicity and prior attainment still strongly predict educational pathways. Beach (2015) argues further that, like other EU nations, the Nordic countries subscribe to a 'pseudomeritocratic' discourse premised on equality of access (See also Haug 1999).

This widespread tendency to segregate curriculum offers on the basis of social class has led to critiques of those who support differentiated routes (for whatever reason), for complacency and elitism. Michael Young (2013), who would regard many of the traditionally valued 'academic' knowledges as 'powerful knowledge', has stated:

Access to powerful knowledge in its diverse forms is an entitlement for all pupils and students. That is why the extent to which a curriculum is underpinned by 'powerful knowledge' is both an epistemological and a social justice issue (p. 196).

Andrew Old (2013), the editor of the Labour Teachers' blog ${ }^{\mathrm{vi}}$, for instance, has pointed to the reactionary heart of 'progressive' educational assumptions around skills-based and/or differentiated curricula that working class pupils are more suited to 'working with their hands'. He maintains that what such commentators deem acceptable educational content for these children they would not see as acceptable for their own. Likewise, Michael Gove (2013b) castigated the liberal Left for its opposition to his ('traditional' academic) English Baccalaureate $^{\text {vii }}$ (EBacc) curriculum, again accusing them of complacency at social class reproduction (see also Peal 2014). 
However, there are tensions at stake in such approaches given: a) the reinscrition of the hierarchical dichotomy in the valuing of some subjects over others (such as e.g. Law over Childcare, and so on); and b) the genuine need to ensure that all young people are engaged in education, which sometimes demands a differentiated curriculum. The focus on the academic curriculum has been critiqued for the way in which it has undermined teachers' professionalism and autonomy by giving them little opportunity to make nuanced judgements about the specific needs of their students or to plan teaching and learning activities that excite students' interests (Hyslop-Margison \& Sears 2010). From a social justice perspective, it has been argued that this primarily works against marginalised students who have had a history of being alienated from traditional curricula (Woods et al. 2014).

These dilemmas are not easily resolved. Our point is that, given these historic and ongoing trends and their consequences for social inequality, more direct attention to the curriculum is required in relation to social justice research (see for example, Zipin 2015).

Clearly, this brings us back to a problem at the heart of this debate, which is who gets to decide what counts as 'the best that has been said and thought': why some knowledges are more valued than others (Young, 2007; see also Young 2011; 2013). We have also

highlighted the problem with equality of access/social mobility models, of which more later. Nevertheless, given the hegemony of the dichotomy illustrated above, and its consequences for life chances, it remains a concern that we educational researchers have not had more to say in analysing and identifying the problems with the status quo, and in modelling alternatives, in effect succumbing to what Fielding and Moss (2010) call the 'dictatorship of no alternative'. In the next section we briefly illustrate a further range of dilemmas and tensions that can be argued to characterise academic work on education and social justice.

\section{Dilemmas of in/justice in education}

We have outlined how issues and debates pertaining to social justice in education remain haunted by binaries around the valuing of different forms of knowledge, liberal or 'traditional' approaches to pedagogy, and the related content of the curriculum. These manifest in longstanding dichotomies, including the aforementioned between knowledge $\mathrm{v}$ skills; that of universal entitlement v local relevance; and (future/academic) outcomes $\mathrm{v}$ student experience of schooling. We sketch the latter two of these here: 
Locally relevant/engaging curricula v national entitlement to 'high status knowledge'. A body of research literature, including the Cambridge Primary Review (Alexander \& Armstrong 2010), shows the importance of curriculum relevance to young people's lives as a precursor to their engagement, which is in turn a precursor to achievement. It has been argued that this is particularly the case for working class students (Hayes et al. 2006), and that the staple curriculum offer does not recognise their experiences. This has led to interventions such as 'funds of knowledge' (see for example, Gonzalez et al. 2005; Zipin et al. 2012) and 'area based curricula' (RSA 2012) which seek to affirm and build on working class students' knowledge and experiences. Similarly, the commitment by many working in remote Indigenous communities to ensuring that Indigenous knowledges are integrated in to the curriculum is evident of a commitment to social justice and a recognition and valuing of 'difference'. The clear problem with such approaches is that, if these 'local knowledges' differ from high status and/or difficult knowledge, the provision of 'engaging' curricula to disadvantaged/marginalised children may further entrench their disadvantage by precluding access to high status education and career paths. Some of the best developed examples (for example, Munns et al. 2013), emphasise that local curricula combined with engaging pedagogies can and must also be 'high cognitive'. In other words, engagement need not be traded for higher order learning. Nevertheless, there remains an insufficient body of work to demonstrate how, in practice, the two goals can be effectively combined.

\section{Future outcomes v engagement (student experience of schooling)}

Education levels and achievements are a predictor of future life chances. Hence, many concerned with equity and social justice stress the importance of inclusion agendas that raise the leaving age of students, and that demand equal application of high expectations to all students irrespective of background. Some also advocate forms of 'tough love' which encourage drill and skill forms of pedagogy, such as Direct Instruction (see the [Australian] National Institute for Direct Instruction 2012), to improve attainment rates (McCollow 2012). However, forgotten in some of these agendas is that students are living in the here and now and experience life in the present not just the future. Research indicates a heavy focus on outcomes increases stress levels for many students (e.g. Hutchings 2015; Howell 2015). Quality of life in the current moment is also a social justice issue (Horgans 2007; Lupton \& Hempel-Jorgensen 2012; Kulz 2015). Raising the question for analysis, to what extent does thriving in later life compensate for being 'oppressed' in the present? 
This returns us to the question of engagement with curriculum content, and young people's preferences/autonomy. Again, there are genuine dilemmas at stake in relation to social justice. Entitlement to material that engages and motivates students has frequently been positioned as a liberal distraction from the priority of delivering positive exam outcomes, reflective of insufficient ambition for working class students on the part of educationalists (Gove 2013b; Old 2013). And as we saw above, it is clear that some approaches to 'engaging' working class students have perpetuated patronising assumptions and low expectations which impede distributive justice. Nevertheless, there is evidence that working class young people, especially, need to see the relevance of their studies in order to motivate their scholarship (Hayes et al. 2006; Perry \& Francis 2010). Engagement and outcomes go hand in hand. There is also evidence that in some primary schools serving socially disadvantaged populations, a focus on 'the basics', and the disciplinary pedagogy adopted to support this, is restricting children's access to the enriched curriculum and more inquiry-led approaches adopted in schools in more affluent areas (Lupton \& Hempel-Jorgensen 2012). A balance between addressing the gaps which young people begin school with, in order to ensure equal entitlement to curriculum and exam success on the one hand, and in ensuring an enriching and empowering school experience on the other, is a difficult one to achieve (Francis 2015).

Thus far we have focused on curriculum and pedagogy. Further dilemmas that arguably 'haunt' the education and social justice literature concern the structures of formal education provision, and include the following:

$\begin{array}{lll}\begin{array}{l}\text { Professional autonomy } \\ \text { Teachers making } a \text { difference }\end{array} & \mathrm{V} & \begin{array}{l}\text { accountability } \\ \text { teachers making the difference }\end{array} \\ \begin{array}{l}\text { Mandatory education } \\ \text { Local democracy }\end{array} & \mathrm{v} & \text { democratic choice } \\ \begin{array}{l}\text { Diversity of provision } \\ \text { Public provision }\end{array} & \mathrm{V} & \text { universal principles } \\ \text { Social diversity } & \mathrm{V} & \text { comprehensive equality } \\ & \mathrm{V} & \text { private provision }\end{array}$

Clearly we cannot do justice to the enormous range of empirical and philosophical research and debate that addresses and/or characterises these various areas. And several of the 
dilemmas we sketch are also present in other areas of social policy. However, there are some distinctive features of the education case which reflect longstanding struggles over delivery and distribution, as well as over content and purposes. While we cannot cover each of these debates in great depth, below we attempt to provide an illustrative précis of each.

\section{Teacher professionalism and autonomy $\mathrm{v}$ accountability.}

In research concerned with social justice there is a strong impetus to support notions of teacher professionalism and autonomy: to trust teachers and their unions as hard working public service professionals, often insufficiently recognised, or belittled, by policymakers. Policies and organisations that seek to hold the profession to account tend to be positioned as pernicious, with attention to their de-professionalising and debilitating effects on teachers (Perryman 2006; Perryman et al 2011; Troman 2000). Yet sociological education research demonstrates the impact of teacher stereotypical expectations on the outcomes of particular student groups (e.g. Gillborn 1995; Archer \& Francis 2007; Gershenson et al. 2016). This raises questions about 'intelligent accountability’ (Sahlberg 2011). How can professional autonomy be maintained and professional practice developed (for example through continuing professional development and inter-school collaboration) while also holding teachers to account for their role in supporting the life chances of the most disadvantaged students?

\section{Teachers making a difference $\mathrm{v}$ teachers making the difference}

Whilst there is clear evidence to show that teachers make a difference to students' social and academic outcomes (Ainscow et al. 2010; Sutton Trust 2015), and to students' engagement with school and take up of post school options (Hayes et al. 2006; Hutchings et al. 2015), the extent to which teachers make a difference is highly contested. In Australia and England, dominant within policy discourses is the suggestion that teachers (and schools) make the difference, and/or should be responsible for closing longstanding gaps in attainment. Whilst this has obvious repercussions in terms of valuing the work of teachers it also serves to mask the ways in which broader social inequities impact on teachers' abilities to disrupt links between students' engagement with school and their socioeconomic backgrounds (Whitty 2016). There are also challenges for researchers to simultaneously acknowledge and support practice which is transforming educational outcomes for pupils from disadvantaged backgrounds in some schools, while also attending to why this may not necessarily be 
realisable at scale (especially given the afore-mentioned broader, entrenched, and often locally-specific, social inequalities).

\section{Mandatory education v democratic choice.}

Can schooling ever be just when it is forcibly imposed on children? Whilst some liberal perspectives emphasize the undemocratic, disengaging and damaging aspects of forcibly subjecting children to the schooling system (see e.g. Illich 1971; Goodman 1971), other perspectives would insist on the importance of the state in providing for all and mediating the inequality which would be - and indeed is - exacerbated without provision of schooling for all, and without measures to enforce regular attendance among those that take it up. Alternative schools which do not attempt to enforce mandatory attendance at classes can also present as problematic (Mills \& McGregor 2014). Within such schools there is a reliance on the attractiveness of the class to encourage attendance. This could be said to be enabling students to exercise their voice or rights (or demonstrating what Fraser [2009] would call political representation). But on the other hand, given it is those most likely to have been disenfranchised by schooling who are most likely not to attend, this encourages provision of less challenging pedagogy (or that that provides interest but without the core material necessary for progression) in order to retain student attendance. In turn such offers risk succumbing to what U.S. President Bush called, and taken up as a critique of progressivism in the Australian political context, 'the soft bigotry of low expectations'.

\section{Local democracy $\mathrm{v}$ universal principles.}

There is a common impetus to enable local democracy and parental involvement in local education decision-making (Compass, 2015), which tends to position centralised, national education policies and/or non-locally representative governance as oppressive. Yet this does not always recognise how 'communities' tend to reflect structural inequalities (with factors such as gender, social class, ethnicity, age and so on impacting on who has representation and 'voice'). Nor does it recognise how 'community views' may be reactionary. (The on-going debate about the provision of sex education, and the safety and acceptance of 'out' LGBTIQ lesbian, gay, bisexual, transgender, intersex, and questioning - teachers, provide familiar examples here) (Ferfolja \& Hopkins 2013).

\section{Diversity of provision v comprehensive equality}


The above dilemma also speaks to the issue of 'school choice', and diversity. As Mills et al (2014) observe, policymakers have established ${ }^{\text {viii }}$ a global trend in the proliferation of differentiated schooling for different 'types' of student. This sometimes reflects segregationist approaches alluded to above. But it also reflects a liberal impulse to individual freedom of choice and plurality. The recent research of one of us (Mills \& McGregor 2014) highlights how the two groups of young people receiving 'bespoke' person-centred education are those in some elite private schools and those in alternative provision (following exclusion from mainstream schooling). It is easy to argue that all pupils should benefit from such approaches, but this is clearly not possible within the current predominant model of state schooling, with its low teacher-to-pupil ratios, and limited material resources (Francis \& Mills 2012b). There is also a danger that child-centred models facilitate a narrowing rather than broadening of horizons, and indeed that 'different strokes for different folks' schooling risks further social segregation (see below).

\section{$\underline{\text { Social diversity } \mathrm{v} \text { recognition of difference (choice) }}$}

There are two issues here. The first is that touched on above - that freedom to make individual choices, and to have distinctions and preferences recognised, is often in tension with the utilitarian needs of the collective. The preference among many in both Australia and England for faith schools illustrates this point well. The challenge is that a) there are limits to the state's ability to provide sufficient 'types' of educational provision to fully represent every discrete aspect of human expression; and b) the more people choose to segregate themselves, the more potentially damaging to social mixing (shown to be educationally and socially beneficial [Angel Alegre \& Ferrer 2010]), and to social cohesion and mutual understanding.

The second tension concerns the notion of social mixing. Researchers tend to applaud social mixing in education as a public good (again, often citing the OECD, which has provided strong evidence of its benefits; OECD 2010; Angel Alegre \& Ferrer 2010). However, when, for example, academy schools with very disadvantaged intakes begin to attract some middle class children, increasing social mix, progressives tend to complain, suggesting that the schools are gaming admissions, and/or the middle classes are drawing down assets, or that the desire to attract middle class students implies a deficit in working class children, who are by implication less valued (see Lupton 2008; Academies Commission 2013, for discussion). On 
the one hand, 'progressives' have argued that the middle classes need to elect into socially mixed schools, but when they do this, they can be positioned as 'colonising' schools.

\section{Public provision $\mathrm{v}$ private provision}

Work in the field tends to reflect an 'unassailable' assumption that privatised provision is always negative (especially for social justice), which promotes a binarised counter assumption that state provision is not just preferable, but positive. Yet the sociological work in the field (internationally) shows that state-provided education has also failed to deliver social justice. While privately delivered systems (via state-subsidised vouchers or otherwise) and for-profit institutions have been shown to result in greater inequality ${ }^{\text {ix }}$ (see Walford 2014), this does not necessarily mean that every item or facility within education provision is necessarily more beneficially produced by the state, or that private offers and products necessarily have nothing beneficial to offer ${ }^{\mathrm{x}}$. Indeed, private schools such as Summerhill (Neil 1960; 1970; Stronach \& Piper 2009) may have something to offer to the government system in relation to social justice by way of, for example, encouraging student voice (see also some schools in Mills \& McGregor 2014). Moreover, as Ball (2013) has shown, the ubiquity of privatised forms, and their complex interweaving with state provision, is far more deeply entrenched within provision in many national contexts than most commentators appear to recognise. Our attention is to the relative paucity of research evidence on their impact and effectiveness or otherwise.

\section{Implications}

Our purpose in this paper has not been to fully elaborate, much less to resolve, these individual dilemmas. The core point we wish to highlight is that how social justice should be advanced in state education is complicated and contested in multiple ways, not just because social justice can be defined in different ways but because what it means in practice is not straightforward either in terms of educational purposes and content, nor in terms of modes of organisation and delivery. Although it is easy to see that we do not currently have a state of social justice, it is not always obvious what the policy prescriptions should be. Gains that are made by following one approach may be offset by losses in other areas.

As the papers we cite, and others, indicate, individual academics understand and recognise these tensions and dilemmas. However, we suggest that as a body, educational researchers 
concerned with social justice (within which we include ourselves) have not yet effectively worked through the binaries identified here in ways which provide a coherent way forward for policy makers in education. Perhaps in response to perceived assaults on social justice within education policy, researchers have tended individually to adopt positions of critique on specific issues (such as marketisation, or high stakes testing), or collectively to reinforce and restate a set of 'progressive principles' - often reflecting the positions on the left hand side of the list of binaries we cite above ${ }^{\mathrm{xi}}$. While it is no doubt important to articulate a concise and clear set of alternative principles upon which education policy could be based, this is, we suggest, not enough. An essential further step is to work through the tensions of actual policy responses as these principles are put into practice, and to support this thinking with evidence and reflection from both sides of each argument. The risk of not doing so is that it is too easy for those in government to dismiss the contribution of educational research as being backward looking (harking back to the 1960s and 70s), lacking both philosophical and empirical clarity and lacking the evidence needed by policymakers and practitioners in order to answer pressing questions about education provision, quality, social in/equality, and value for money.

A further illustration of our argument is the recent interventions on 'heredity' and educational outcomes (Shakeshaft et al 2013), and extension to social background (e.g. The Spectator 2014). Although the perceived implications of some of these findings are deeply problematic from social justice perspectives, few of us are in any position to effectively engage and contest them, due to a general lack of engagement with the field of genetics and neuroscience in relation to education. (For notable exceptions, see e.g. the work of Goswami, 2006; Tolmei, 2015; and Jerrim et al, 2014). This is arguably of especial concern given the emergent findings from the field of epigenetics, which is highlighting the impact of (social) environment on heredity (Rose 2013). Our argument is that we must be prepared to confront difficult topics, and to interrogate the consequences of our evidence and principles, if we are to effectively promote more socially just education. We otherwise risk this work being left to those in other fields more prepared to engage with pragmatic policy questions (such as economists) or to the implications of emergent research areas (such as neuroscientists).

As we have asserted previously, we need urgently to "build on our existing empirical and philosophical research to develop new ideas and constructive principles and practices for the provision of socially-just education." (Francis \& Mills, 2012a p. 584). We maintained that 
this would demand two key elements. First, an open-minded reappraisal of the dilemmas which we began to trace in that article, and have further elaborated above; including an interrogation of our investment in the narratives that feed the dichotomies that underpin those dilemmas. As we argued, this comprises "an essential prerequisite to ensure that our responses are not simply reactionary, but rather are constructive and future-focused" (Francis \& Mills 2012a, p. 584).

We argued secondly that we ought to simultaneously engage pragmatic and 'utopian' thinking, in order to enable us to continue to think ambitiously while also constructively confronting the necessities of the present. This of course implies a return to first principles, and the analysis of what a socially just education system would look like (Francis \& Mills 2012a). As Beach (2015) argues, 'rights as distributed access' - the model to which most countries in the Global North ostensibly subscribe (at least to some extent) - is not sufficient to achieve or constitute social justice. This is because the equality of opportunities model (which reflects the theoretical commitment to social mobility) still accepts inequities and inequalities as natural, and even as valuable (Beach 2015; Cole 2003). Indeed, Cole (2003) refers to a 'right to inequality', which he argues to be closely guarded by Western states. According to Jonsson and Beach (2015) it is such assumptions of inequalities that both reflect and precipitate the assumptions about differentiated schooling and content that Mills et al (2014) and others have shown to characterise policy developments across Western nations: young people are subjected to principles of differentiation wherein their difference and inequality is taken as a prior assumption from which educational 'offers' follow (Beach 2015). Young people are then sorted into different institutions/educational routes accordingly, reflecting and perpetuating inequalities of social class, gender, and ethnicity.

This reflection and appraisal is difficult, and there is insufficient space here to engage it. It is also especially challenging to hold together the utopian and the pragmatic, given that so much current education policy and practice is clearly so tightly constrained by finance. In both our national contexts, significantly raising taxation appears politically untenable, and in the British case policies are radically circumscribed by the context and practice of fiscal austerity. As we have discussed elsewhere, raw cost underpins numerous elements of the present dominant model of education that contribute to injustice (Francis \& Mills 2012b). But also, we feel that we are constrained by the very narrow outcome measures that speak to educational distribution rather than recognition, and disproportionately prioritise outputs 
(credentials) over experiences. Moreover, these outputs are narrowly conceived, focused largely on measures of the extent to which discrete curriculum knowledge can be reproduced in the short term.

There are signs that more preferable, diverse outcome measures are emerging. In Queensland, Australia, for example, the State government partnered with a university research team to develop the concept 'rich accountabilities' to better understand the work of schools in that state (details and references to be provided upon acceptance for publication). In the UK context, England has recently embarked on the 'Progress 8' measure, which seeks to incentivise and reward a range of just practices. For example, it analyses individual pupil progress, rather than raw outcome; recognising uneven starting points and rewarding the contribution a school has made. As outcomes in 8 subject choices can 'count' towards the measure, it incentivises schools to focus on supporting pupils in 8 curriculum areas encouraging entitlement to a broad curriculum but with 'high status' knowledge at the heart. The stipulation of choices from different 'baskets' of subjects ensures that this broad curriculum is also balanced - and can facilitate routes to higher study (Paterson, 2012). Hence this indicator seeks to support justice in terms of entitlement for all, but comprises an impressively 'strong' model in this regard, as it actively incentivises support for lower attainers as well as middle and higher attainers (the former having been disregarded in prior models). Likewise, perhaps concerned at its apparent endorsement of some of the most intensive and 'drilled' education provision in the world via its existing assessment measures, the OECD has embarked on development and implementation of a set of measures to test creativity (OECD 2012). These various approaches hint at the range of indicators which might be used to monitor aspects of in/justice in education; and we believe that a wider set of indicators is inevitably needed to do so. Turning the tables between purposes and outcomes, it is possible that thinking about what we wish educational experiences and outcomes to comprise, provides a social justice lens in interrogating provision.

\section{Conclusion}

This paper has been written as a provocation to those, who like us, are concerned by what we see as the multiple oppressions perpetrated by and through schooling against those who come from marginalised backgrounds whether characterised by social class, economic 
circumstances, race, ethnicity, sexuality, age and/or physical ability. However, we also subscribe to the position of Connell (1993, p.15) that:

If the school system is dealing unjustly with some of its pupils, they are not the only ones to suffer. The quality of education for all the others is degraded (original emphasis).... The issue of social justice is not an add-on. It is fundamental to what good education is about.

What we have demonstrated though in this paper is that tackling injustice is not a straight forward task. In the introduction to a key text examining the work of social justice philosopher Nancy Fraser, Kevin Olson suggests that in the current moment, there is an 'absence of any shared vison of justice on the left' (Olson 2008, p.2). He goes on to say: 'Today, in fact, we find little agreement among progressives as to what counts as a genuine injustice, let alone as to how to overcome it'. It is such a lack of agreement that lies at the heart of many of the tensions and dichotomies that we have covered here. Indeed, as many of the contributors to that text argue, some strategies to address matters of injustice may well contribute to greater injustices.

In this paper, as noted earlier, we have not sought to provide definitive answers to each of the dichotomies we raise here. What we have done is to identify what we see as key points of tension that require addressing by those who are concerned about social justice issues and education as they relate to curriculum and the structures of schooling. Many of the conundrums that we identify may not be solvable within the current organisation of schooling. Indeed, constructing a vison of what a socially just education system may require a complete rethink of what constitutes a school. It may involve a form of utopian thinking which goes beyond 'affirmative' approaches to addressing social injustice to 'transformative ones', that is those that correct 'inequitable outcomes ... by restructuring the underlying generative framework' (Fraser, 1997, p. 23). However, such a step is not possible without a robust conversation about the purposes of schooling, about the relationships between those purposes and social justice, and about how some of the tensions raised in this paper might best be resolved within an understanding of the complexities of these relationships. These debates also need to be informed by the provision and evaluation of rigorous research evidence, both qualitative and quantitative, including longitudinal work tracking the impact of different policy approaches on student experiences and educational outcomes. We believe 
that confrontation of these dilemmas may generate fruitful research programmes that can contribute constructively to both utopian and pragmatic policy agendas to support educational equality.

\section{References}

Alexander, R. J., \& Armstrong, M. 2010. Children, their world, their education: Final report and recommendations of the Cambridge Primary Review. Taylor \& Francis US.

Apple, M. W. 2006. Educating the" right" way: Markets, standards, God, and inequality. London: Taylor \& Francis.

Angel Alegre, M. and G. Ferrer. 2010. School regimes and education equity: some insights based on PISA 2006, British Educational Research Journal, 36 (3): 433-461.

Apple, M. and Beane J. (Eds). 1999. Democratic Schools: Lessons from the Chalkface. Buckingham: Open University Press.

Arendt, H. 1954. 'The Crisis of Education', The Digital Counter-revolution, http://www.digitalcounterrevolution.co.uk/2012/the-crisis-of-education-hannah-arendt/ (accessed 15.7.16)

Archer, L. \& Francis, B. 2007. Understanding Minority Ethnic Achievement, London: Routledge.

Arnold, Matthew. (1869) Culture and Anarchy: An Essay in Political and Social Criticism. Oxford: Project Gutenberg. pp. viii, 7, 15-16.

Arnot, M., Weiner, G., \& David, M. 1999. Closing the Gender Gap, Buckingham: Open University Press.

Ball, Stephen. 2012. Global Education Inc.: New policy networks and the neoliberal imaginary, Routledge: London.

Ball, S. 2013. (2nd Ed.) The Education Debate, Bristol, The Policy Press

Beach, D. 2015. Education and Justice: An analysis from the Nordic countries, The 5th International Conference on Critical Education, Wroclaw, Poland, June 15-18.

Blanden, J. and Macmillan, L. 2013. Education and Intergenerational Mobility: Help or Hindrance? London: CASE, LSE.

Bleazby, J. 2015. Why some school subjects have a higher status than others: The epistemology of the traditional curriculum hierarchy. Oxford Review of Education, 41(5), 671-689.

Burgess, S. 2014. Understanding the success of London's schools. Working Paper 14/333. Bristol, Centre for Market and Public Organisation (CMPO) 
CfBT 2014. Lessons from London Schools: Investigating the Success. CfBT.

http://cdn.cfbt.com/ /media/cfbtcorporate/files/research/2014/r-

london-schools-2014.pdf

Campbell, C. \& Proctor, H. 2014. A History of Australian Schooling, Sydney: Allen \& Unwin.

Candy, S. 2013. (Un)Informed Choices? London: The Pearson ThinkTank.

Compass. 2015. Big Education, London: Compass.

Cole, M. 2003. Might it be in the Practice that it Fails to Succeed? A Marxist critique of claims for postmodernism and poststructuralism as forces for social change and social justice, British Journal of Sociology of Education, 24(4) 487-500.

Collins, C. and Yates, L. 2011. Confronting equity, retention and student diversity. In L. Yates, C. Collins, \& K. O'Connor (Eds.), Australia's Curriculum Dilemmas: State cultures and the big issues (pp. 107-126). Carlton: Melbourne University Press

Connell, Raewyn 1993. Schools and social justice. Philadelphia: Temple University Press.

Cousins, A. \& Mills, M. 2015. Gender and high school chemistry: student perceptions on achievement in a selective setting. Cambridge Journal of Education, 45(2), 187-204.

Fielding, Michael and Moss, Peter. 2010. Radical Education and the Common School: A democratic alternative, London: Routledge .

DfE. 2016. GCSE and equivalent results, including pupil characteristics, London: DfE. https://www.gov.uk/government/statistics/revised-gcse-and-equivalent-results-in-england-

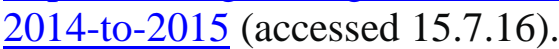

DfE. 2016. White Paper: Educational Excellence Everywhere, London: Her Majesty's Stationary Office.

Ferfolja, T., \& Hopkins, L. 2013. The complexities of workplace experience for lesbian and gay teachers. Critical Studies in Education, 54(3), 311-324.

Fielding, M. \& Moss, P. (2011). Radical education and the common school: A democratic alternative. London: Routledge.

Ford, M. (2013). Achievement gaps in Australia: What NAPLAN reveals about education inequality in Australia. Race Ethnicity and Education, 16(1), 80-102.

Francis, B. (2014) Impacting policy discourse? An analysis of discourses and rhetorical devices deployed in the case of the Academies Commission. Discourse: Studies in the Cultural Politics of Education. 36(3) 437-451

Francis, B. (2015) Unlocking the potential of all pupils: High achievement irrespective of background. In: Lessons Learned: Putting Experience to Work. London: ARK. http://arkonline.org/sites/default/files/Ark_lessons_learned.pdf 
Francis, B. \& Mills, M. (2012a) What would a socially-just education system look like?, Journal of Education Policy, 27(5), 577-585

Francis, B and Mills, M (2012b) Schools as damaging organizations, Pedagogy, Culture \& Society. 20(2), 251-271.

Francis, B. \& Skelton, C. (2005) Reassessing Gender and Achievement, London: Routledge.

Fraser, Nancy (1997). Justice interruptus: Critical reflections on the "postsocialist" condition, New York: Routledge.

Fraser, Nancy (2009). Scales of justice: Reimagining political space in a globalizing world, New York: Columbia University Press.

Gandin, Luiz A. \& Apple, Michael. 2002. Challenging neo-liberalism, building democracy: creating the Citizen School in Porto Alegre, Brazil. Journal of Education Policy, 17 (2), 259279.

Gershenson, S., Holt, S., \& Papageorge, N. 2016. Who believes in me? The effect of studentteacher demographic match on teacher expectations, Economics of Education Review, http://www.sciencedirect.com/science/article/pii/S0272775715300959

Gewirtz, Sharon, Ball, Stephen \& Bowe, Richard. 1995. Markets, choice, and equity in education, Buckingham: Open University Press.

Gillborn, D. 1995. Racism and Anti-Racism in Real Schools, Buckingham: Open University Press.

Goodman, P. 1971. Compulsory miseducation. Harmondsworth: Penguin.

Goswami, U. 2006. Neuroscience and education: from research to practice? Nature Reviews Neuroscience 7, 406-413

Gove, M. 2013. 'I refuse to surrender to the Marxist teachers hell-bent on destroying our schools: Education Secretary berates 'the new enemies of promise' for opposing his plans', Mail Online, 23.3.13.

http://www.dailymail.co.uk/debate/article-2298146/I-refuse-surrender-Marxist-teachers-hellbent-destroying-schools-Education-Secretary-berates-new-enemies-promise-opposingplans.html Accessed 13.5.16.

Gove, M. 2013b. 'The Progressive Betrayal', speech to the Social Market Foundation, 13.2.13. http://www.smf.co.uk/michael-gove-speaks-at-the-smf/ (accessed 15.7.16).

Greaves, E., Macmillan, L. and Sibieta, L. 2014. Lessons from London schools for attainment gaps and social mobility. SMCP Research Report SMCP-RR363. London: Social Mobility and Child Poverty Commission. 
Harrison, N., James, D. and Last, K. 2015. Don't know what you've got 'til it's gone? Skillsled qualifications, secondary school attainment and policy choices. Research Papers in Education, 30 (5), 585-608.

Haug, P. 1999. Formulation and realisation of social justice: the compulsory school for all in Sweden and Norway, European Journal of Special Needs Education, 14(3): 231-239.

Hayes, D., Mills, M., Christie, P. \& Lingard, B. 2006. Teachers and schooling making a difference: Productive pedagogies, assessment and performance, Sydney: Allen \& Unwin.

Heath, A., Sullivan, A., Boliver, V., and Zimdars, A. 2013. 'Education under New Labour, 19972010'. Oxford Review of Economic Policy, 29 (1), 227-47.

Hillman, N. \& Robinson, N. 2016. Boys to Men: The underachievement of young men in higher education - and how to start tackling it. London: HEPI.

Hirsch, E.D. 1996. The Schools We Need and Why We Don't Have Them, New York: Anchor Books.

Hogan, A. 2014. NAPLAN and the role of edu-business: New governance, new privatisations and new partnerships in Australian education policy. The Australian Educational Researcher, $1-18$.

Horgan, Goretti. 2007. The Impact of Poverty on Young Children's Experience of School. York: Joseph Rowntree Foundation.

Howell, A. 2015. Exploring children's lived experiences of NAPLAN. In B. Lingard, G. Thompson \& S. Sellar (Eds) National Testing in Schools: An Australian Assessment, Routledge, Oxon, 164-180.

Hutchings, M. 2015. Exam Factories: The impact of accountability measures on children and young people, London: National Union of Teachers.

Hyslop-Margison, EJ, and Sears, AM. 2010. Enhancing teacher performance: The role of professional autonomy, Interchange. 41(1): 1-15.

Ianelli, C. 2013. The role of the school curriculum in social mobility. British Journal of Sociology of Education, 34(5) 907-928.

Illich, Ivan. 1971. De-Schooling Society, Harmondsworth: Penguin.

Jerrim, J. 2012. The reliability of trends over time in international education test scores: Is the performance of England's secondary school pupils really in relative decline? Journal of Social Policy $42(2), 259-79$.

Jerrim, J., Vignoles, A., Lingam, R. \& Friend, A. (2014) The socio-economic gradient in children's reading skills and the role of genetics, British Educational Research Journal. 41(29): 6-29. 
Jonsson, A. \& Beach, D. 2015. Institutional discrimination: Stereotypes and social reproduction of "class" in the Swedish upper-secondary school, Social Psychology of Education, 18 (4) 703-717

Keddie, A. 2012a. Educating for Diversity and Social Justice. Routledge: New York.

Keddie, A. 2012b. Schooling and social justice through the lenses of Nancy Fraser. Critical Studies in Education, 53(3), 263-279.

Kulz, Christy. 2014. "Structure Liberates?": Mixing for Mobility and the Cultural Transformation of "urban Children" in a London Academy. Ethnic and Racial Studies 37 (4): $685-701$.

Lingard, B. 2010. Policy borrowing, policy learning: Testing times in Australian schooling. Critical Studies in Education, 51(2), 129-147.

Lingard, B., Sellar, S., \& Savage, G. C. 2014. Re-articulating social justice as equity in schooling policy: The effects of testing and data infrastructures. British Journal of Sociology of Education, 35(5), 710-730.

Lupton, R., Heath, N. \& Salter, E. (2009) Education: New Labour's top priority, in Hills J, Sefton T and Stewart K (eds) Towards a more equal society? Poverty, inequality and policy since 1997, Bristol: Policy Press.

Lupton, R., \& Hempel-Jorgensen, A. (2012). 'The Importance of Teaching: Pedagogical Constraints and Possibilities in Working-Class Schools'. Journal of Education Policy 27 (5): 601-20.

Lupton, R. and Obolenskaya, P. (2013) Labour's Record on Education 1997-2010. Social Policy in a Cold Climate Working Paper WP03, London, Centre for Analysis of Social Exclusion.

Lupton, R and Thomson, S. (2015) Socio-economic inequalities in English schooling under the Coalition Government 2010-2015. London Review of Education 13 (2) pp 4-20.

Maguire, M., Wooldridge, T. and Pratt-Adams, S. 2006. The Urban Primary School, Maidenhead: Open University Press.

McCollow, J. 2012. A Controversial Reform in Indigenous Education: The Cape York Aboriginal Australian Academy. The Australian Journal of Indigenous Education, 41(02): 97-109.

McGregor, G. \& Mills, M. 201). Alternative education sites and marginalised young people: 'I wish there were more schools like this one'. International Journal of Inclusive Education, 16(8): 843-862.

Mills, M., Keddie, A., Renshaw, P. \& Monk, S. (in press) The Politics of Differentiation in Schools, London, Routledge.

Mills, M. \& McGregor, G. (2014) Re-engaging young people in education: learning from alternative schools, London: Routledge. 
Mills, M., \& McGregor, G. (2016). Learning not borrowing from the Queensland Education System: Lessons on curricular, pedagogical and assessment reform, The Curriculum Journal, 27 (1) 113-133

Mills, M., Monk, S., Keddie, A., Renshaw, P., Christie, P., Geelan, D., \& Gowlett, C. (2014) Differentiated learning: policy to classroom, Oxford Review of Education, 40(3) 331-348.

Munns, G, Sawyer, W, and Cole, B., (eds.). 2013. Exemplary Teachers of Students in Poverty. London and New York: Routledge.

National Institute for Direct Instruction (NIFDI). 2012). AboutDI. Retrieved from http://www.nifdi.org/15/aboutdi 28/4/2016.

Neill, A. 1970. Summerhill: For \& against. New York: Hart.

Neill, A. S. 1960. Summerhill: A Radical Approach to Child Rearing. New York: Hart.

Peal, R. 2014. Progressively Worse: The burden of bad ideas in British schools, London: Civitas.

Perryman, J. 2007. Panoptic performativity and school inspection regimes: disciplinary mechanisms and life under special measures, Journal of Education Policy, 21 (2) 147-161.

Perryman, J., Ball, S., Maguire, M. \& Braun, E. 2011. Life in the Pressure Cooker - School League Tables and English and Mathematics Teachers' Responses to Accountability in a Results-Driven Era, British Journal of Educational Studies, 59(2) 179-195.

Old, A. 2013. 'How the Education Establishment Supports Inequality', 1.3.15 https://teachingbattleground.wordpress.com/

OECD. 2010a. Viewing the United Kingdom School System Through the Prism of PISA. Paris, OECD.

OECD. 2012. PISA 2012 Results: Creative Problem Solving: Students' skills in tackling reallife problems (Volume V) http://www.oecd.org/pisa/keyfindings/pisa-2012-results-volumev.htm Accessed 13/6/16

OECD. 2013. PISA in Focus 25: Are Countries Moving Toward More Equitable Education Systems? Paris: OECD. http://www.oecd.org/pisa/pisainfocus/pisa\%20in\%20focus\%20n25\%20(eng)--FINAL.pdf

Olson. K. 2008. Adding insult to injury: An introduction. In K. Olson (Ed) Adding insult to injury: Nancy Fraser debates her critics London: Verso, pp.1-8.

Paechter, C. 2000. Changing School Subjects: Power, gender and curriculum, London: Routledge.

Paterson, C. 2012. Measuring What Matters: Secondary school accountability measures that benefit all, London: CentreForum. 
Perry, E., and Francis, B. 2010. The social class gap for educational achievement: a review of the literature. RSA Projects.

Purvis, June. 1989. Hard lessons: lives and education of working class women in nineteenth century England. In: Feminist perspectives: Polity Press.

Richmond, T. \& Freedman, S. 2009. Rising Marks, Falling Standards, London: Policy exchange.

Rizvi, F., \& Lingard, B. 2009. Globalizing education policy. London: Routledge.

Rose, N. 2013. The Human Sciences in a Biological Age, Theory, Culture \& Society, 30 (1): 3-34.

RSA. 2012. The Area Based Curriculum, London: The RSA.

Russell Group. 2012. Informed Choices. London: The Russell Group. URL: http://www.russellgroup.ac.uk/informed-choices/

Sahlberg, P. 2011. Finnish Lessons: What can the world learn from educational change in Finland? New York: Teachers' College Press.

Sellar, S., \& Lingard, B. 2013. The OECD and global governance in education. Journal of Education Policy, 28(5), 710-725.

Sellar, S., \& Lingard, B. 2014. The OECD and the expansion of PISA: New global modes of governance in education. British Educational Research Journal, 40(6), 917-936.

Sen, A. 2011. The idea of justice. Cambridge, Massachusetts: Harvard University Press.

Shakeshaft NG, Trzaskowski M, McMillan A, Rimfeld K, Krapohl E, Haworth CMA, Dale, P. \& Plomin, R. 2013. Strong Genetic Influence on a UK Nationwide Test of Educational Achievement at the End of Compulsory Education at Age 16. PLoS ONE, 8(12): e80341. doi:10.1371/journal.pone.0080341

The Spectator. 2013 'Revealed: how exam results owe more to genes than teaching'. Mary Wakefield in: The Spectator, 27.7.13, http://www.spectator.co.uk/2013/07/sorry-butintelligence-really-is-in-the-genes/

Stinson, M., \& Saunders, J. N. 2016. Drama in the Australian national curriculum: decisions, tensions and uncertainties. Research in Drama Education: The Journal of Applied Theatre and Performance, 21(1), 93-104.

Strand, S. 2011. The limits of social class in explaining ethnic gaps in educational attainment, British Educational Research Journal 37(2): 197-229

Stronach, I. \& Piper, H. 2009. The touching example of Summerhill School. In Woods, P. A. and Woods, G. J. eds. Alternative Education for the 21 st century: Philosophies, approaches, visions. New York: Palgrave Macmillan, pp. 49-64.

Sutton Trust. 2015 Subject to Background, London: Sutton Trust. 
Teese, R., \& Polesel, J. (2003). Undemocratic schooling: Equity and quality in mass secondary education in Australia. Melbourne Univ. Publishing.

Terwel, J. 2006. Curriculum differentiation: multiple perspectives and developments in education, Journal of Curriculum Studies, 37(6): 653-670.

Thompson, Greg. 2013. NAPLAN, MySchool and accountability: Teacher perceptions of the effects of testing. International Education Journal, 12(2), pp. 62-84.

Thrupp, Martin. 1999. Schools Making a Difference: Let's Be Realistic! First Edition edition. Buckingham England; Philadelphia: Open University Press.

Tolmei, A. 2015. Neuroscience of education. In J.D. Wright (Ed.), The International Encyclopedia of the Social and Behavioral Sciences (2 ${ }^{\text {nd }}$ Edition). Oxford: Elsevier.

Troman, G. 2000. 'Teacher Stress in the Low-Trust Society', (2000) British Journal of Sociology of Education, 21 (3): 331-353.

Walford, G. 2014. From city technology colleges to free schools: sponsoring new schools in England. Research papers in education, 29(3), 315-329.

Wilkinson, Richard and Pickett, Kate. 2010. The Spirit Level: Why equality is better for everyone (London: Penguin Books).

Whitty, G. With Anders, J., Hayton, A., Tang, S. \& Wisby, E. 2016. Research and Policy in Education, London: UCL IOE Press.

Wolf, A. 2011. Review of Vocational Education - The Wolf Report. DfE, London.

Woods, P. and Woods, G. (eds). 2009. Alternative Education for the 21 st century: Philosophies, approaches, visions. New York: Palgrave Macmillan

Woods, A, Dooley, K, Luke, A \& Exley, B. 2014. School Leadership, Literacy and Social Justice: The Place of Local School Curriculum Planning and Reform International Handbook of Educational Leadership and Social (In)Justice, Eds: I Bogotch \& C Shields, Springer, New York, pp. 509-520.

Young, Iris. 2004. "Five Faces of Oppression". In: Maree Heldke, Lisa; O'Conor, Peg. Oppression, Privilege, and Resistance: Theoretical Perspectives on Racism, Sexism, and Heterosexism (PDF). McGraw-Hil. pp. 37-63.

Young, M. 1958. The Rise of the Meritocracy, London: Pelican.

Young, M. 2007. Bringing knowledge back in: From social constructivism to social realism in the sociology of education. Routledge, 2007.

Young, M. 2011. 'Curriculum policies for a knowledge society?', in Curriculum in today's world: Configuring knowledge, identities, work and politics, Eds: L Yates \& M Grumet, Routledge, London, pp 125-138. 
Young, M. 2013. Powerful knowledge: An analytically useful concept or just a 'sexy sounding term? A response to John Beck's 'Powerful knowledge, esoteric knowledge, curriculum knowledge', Cambridge Journal of Education, 43( 2): 195-198.

Zipin, L., Sellar, S. \& Hattam, R. 2012. Countering and exceeding 'capital': a 'funds of knowledge' approach to re-imagining community, Discourse: Studies in the Cultural Politics of Education, 33 (2), 179-192.

Zipin, L. 2015. Chasing curricular justice: How complex ethical vexations of redistributing cultural capital bring dialectics to the door of aporia. Southern African Review of Education, 21(2): 91-109.

\footnotetext{
${ }^{\mathrm{i}}$ Albeit of course care is needed here; see for example, Skelton \& Francis, 2007; Archer et al, 2013; Cousins and Mills, 2015

ii It is notable that while much critique is directed at the OECD for their role in the development of global audit and new managerialist practices in education, social justice researchers also frequently make recourse to citing OECD evidence when needing to highlight educational inequalities and so on.

iii For a discussion of some of the conceptual challenges with the concept of meritocracy, see Young (1958).

${ }^{\text {iv }}$ It has also developed other programmes aimed at promoting the educational attainment of pupils from low SES backgrounds, including the Pupil Premium, and the sponsor academies programme (Francis and Wong, 2013).

'A collection of GCSEs in 'traditional' academic subject areas, see:

https://www.gov.uk/government/publications/english-baccalaureate-ebacc/english-baccalaureate-ebacc

${ }^{v i}$ See http://www.labourteachers.org.uk/author/editor/

vii See endnote $\mathrm{v}$

viii Frequently via engagement/negotiation with the unions; see Mills et al., 2014.

${ }^{i x}$ Sahlgren (2012) claims that this has been due to the poor quality/vision of systems adopting voucher systems, rather than the mechanism itself, which he sees as potentially emancipatory. However, without exemplars of success in this regard, this argument seems to lack credibility.

${ }^{\mathrm{x}}$ For example, several researchers have explored efforts towards democratic education provided by some feepaying schools (Mills \& McGregor 2014; Woods \& Woods 2009). Moreover, the provision of products such as textbooks by private publications houses does (at least to some extent) avoid potential challenges that can arise when such products are provided by the State.

${ }^{x i}$ Recent examples of such collective action can be found in the British Educational Research Association social justice 'manifesto' produced before the 2015 UK general election (in which some of the authors were involved) and in the National Union of Teachers manifesto 'Stand Up for Education' at the same time.
} 